\title{
Når verre blir verst og veien hjem 进
}

\author{
Fredag 22. juli 2011 har satt dype spor i den norske folkesjelen. Den har satt dype spor i ofrene som \\ overlevde, og den har satt dype spor hos oss som deltok som helsepersonell.
}

Med knapt ti års erfaring som luftambulanselege kan jeg trygt si at dette er det mest ekstreme jeg har opplevd, og jeg håper ingenting vil overgå det $i$ fremtiden.

Den prehospitale innsatsen i forbindelse med bomben i Regjeringskvartalet og skytingen på Utøya var formidabel. Ambulansetjenester fra flere helseforetak, seks luftambulansehelikoptre, Forsvarets redningshelikopter, lokale anestesiavdelinger og en rekke frivillige organisasjoner deltok i redningsarbeidet. I skrivende stund er vi fortsatt $\mathrm{i}$ prosessen med å samle data fra innsatsen, og det gjenstår et omfattende evalueringsarbeid som forhåpentligvis vil bidra til å styrke den prehospitale katastrofeberedskapen ytterligere.

\section{Tungt ikke å slippe til}

To katastrofale hendelser så tett på hverandre legger et stort press på de prehospitale tjenestene. I dette tilfellet var imidlertid omfanget av personskader i Oslo mindre enn fryktet, og alle de alvorlig skadede var tatt hånd om da meldingene om skyting på Utøya kom inn. Katastrofeapparatet var åstedet. Vi viste imidlertid tidlig at det dreide seg om et stort antall alvorlig skadede og døde, og det var tungt å måtte holde igjen på ønsket om å hjelpe. Når det er sagt, strakk nok mange av oss begrepet egensikkerhet langt. I ettertid vet vi at vi var utenfor fare etter at gjerningsmannen var pågrepet, selv om usikkerheten rundt antallet gjerningsmenn vedvarte i flere timer etterpå.

\section{Rask transport}

Den første organiserte helseinnsatsen med mottak, triage og behandling av de skadede som kom fra Utøya, foregikk på landsiden og var preget av en stor tilstrømning av til dels meget hardt skadede pasienter på kort tid. Politiet og sivile båteiere gjorde en formidabel innsats med å bringe de hardest skadede til land så raskt som mulig. Det var initialt ikke tid til å organisere en samleplass, men med en kraftanstrengelse klarte vi å vurdere, stabilisere og iverksette meget rask transport av alle disse pasientene. Mitt inntrykk er at grunnen til at dette i det hele tatt lot seg gjøre, var den tidlige innsatsen

\section{«Den prehospitale innsatsen i forbindelse med bomben i Regjeringskvartalet og skytingen på Utøya var formidabel»}

allerede aktivert, og utfordringen lå i å rokere ressursene. Luftambulanseavdelingen på Oslo universitetssykehus kunne derfor stille med begge sine legehelikoptre, seks innkalte luftambulanseleger, to innkalte sykepleiere og to fra ambulansepersonellet. Luftambulansehelikoptre fra Ål, Dombås, Arendal og Stavanger ble også dirigert mot Utøya sammen med redningshelikoptrene fra Rygge og Ørlandet, legevaktsleger fra Ringerike og hele 42 ambulanser fra alle de store tjenestene på Østlandet. Anestesipersonell fra Bærum og Drammen var også en viktig del i det prehospitale arbeidet.

Den største frustrasjonen for oss som deltok i redningsarbeidet fra den prehospitale spesialisthelsetjenesten, var at vi ikke slapp til umiddelbart. Situasjonen var uoversiktlig de første timene. Det var uklart om det var flere gjerningsmenn, og helsepersonell var angivelig blitt skutt på. Det er derfor meget forståelig at politiet var forsiktig med å slippe helsepersonell for nært til en rekke erfarne luftambulanseleger med nødvendig kompetanse og erfaring fra triage og akutt primærbehandling.

\section{Redningsarbeidet på Utøya}

Da det første mottaksstedet etter kort tid ble evakuert grunnet en potensiell sikkerhetsrisiko, ble mottak og samleplass flyttet, mens en liten gruppe av oss tok oss ut til Utøya for å bistå der. Den nye samleplassen ved brua til Storøya ble forbilledlig organisert med til sammen syv anestesiteam, seks luftambulansehelikoptre, to redningshelikoptre og 39 bilambulanser. I tillegg stilte kommunehelsetjenesten og helseekspressen opp for å ivareta dem som ikke var fysisk skadet.

Vi som ble med ut på selve Utøya, tok i mot en liten gruppe skadede og ble ikke eksponert for den store pågangen med tilskadekomne som vi hadde fryktet. De fleste overlevende som var igjen på øya, var uskadede og i skjul. Vi kunne derfor trappe ned bemanningen på Utøya utover kvelden, men valgte å beholde en beredskap hvis det skulle dukke opp flere skadede. Da kollega Jan Erik Nilsen og jeg, som de siste legene, reiste fra øya etter midnatt hadde vi deltatt $i$ et siste søk etter overlevende blant de omkomne som var igjen.

\section{Godt å kunne bidra}

Selv om man som luftambulanselege er eksponert for mange tragedier og alvorlige skader i yrket, var opplevelsen med arbeidet ved og på Utøya en stor belastning for oss alle. For min egen del har et godt nettverk av kolleger, nære venner og familie vært det viktigste midlet for å bearbeide dette.

Vårt bidrag i redningsarbeidet var kun en del av kjeden som reddet liv, men jeg er takknemlig for at vi kunne bidra. Jeg tror at den prehospitale spesialisthelsetjenesten fikk utrettet mye godt denne dagen. I vårt fagmiljø vil derfor 22. juli 2011 også huskes for den fantastiske innsatsen som ble utført av alle hjelperne, både de frivillige og de profesjonelle.

\section{Stephen J.M. Sollid}

stephen.sollidanorskluftambulanse.no Luftambulanseavdelingen

Akuttklinikken

Oslo universitetssykehus

Stephen J.M. Sollid (f. 1972) er overlege ved Luftambulanseavdelingen, Akuttklinikken ved Oslo universitetssykehus og fagsjef i Stiftelsen Norsk Luftambulanse.

Ingen oppgitte interessekonflikter.

Mottatt 30.8. 2011 og godkjent 30.8. 2011.

Medisinsk redaktør Erlend Hem.

Engelsk oversettelse av hele artikkelen på www.tidsskriftet.no 